\title{
Blended E-Learning in Higher Education: Research on Students' Perspective
}

\author{
Marta Žuvic-Butorac, Faculty of Engineering \\ Nena Roncevic, Faculty of Humanities and Social Sciences \\ Damir Nemcanin, Faculty of Engineering \\ Zoran Nebic, Faculty of Engineering \\ University of Rijeka, Rijeka, Croatia
}

martaz@riteh.hr; nroncevic@ffri.hr;

dnemcanin@riteh.hr; znebic@riteh.hr

\begin{abstract} of the learning process.

Material published as part of this publication, either on-line or in print, is copyrighted by the Informing Science Institute. Permission to make digital or paper copy of part or all of these works for personal or classroom use is granted without fee provided that the copies are not made or distributed for profit or commercial advantage AND that copies 1) bear this notice in full and 2) give the full citation on the first page. It is permissible to abstract these works so long as credit is given. To copy in all other cases or to republish or to post on a server or to redistribute to lists requires specific permission and payment of a fee. Contact Publisher@InformingScience.org to request redistribution permission.
\end{abstract}

The process of implementing blended learning, by using e-learning tools as a support for traditional classroom teaching, started at the University of Rijeka at the beginning of 2008, following general strategic principles adapted to local environment. The process has been constantly supported and assessed for quality, but up to now only from the institutional, teachers' and support services' perspective. Assuming that continuous and careful monitoring of learner's satisfaction is important for the success, feasibility and viability of e-learning, we conducted the research on students' perspective. As the student's perception regarding e-learning is one of the most important steps in developing and implementing a successful e-learning environment, we conducted the study of student's perception and e-learning acceptance, with three specific items addressed in the study: 1) student's perception of quality of already delivered e-courses, 2) level of importance for the specific elements of e-learning encountered, and 3) student's general attitude towards elearning and their needs with respect to quality of course materials, communication and support

Participants in the study assessed the current state of e-learning elements implementation quite good; they agreed the educational materials were in most cases complete, organized and well designed, and they considered the ability of teachers to manage the e-courses well, communication regular as well as the provision of the feedback. The lower level of agreement was obtained on the use of multimedia, offering of the self-assessment tests, accessibility of digital literature and collaborative activities. This suggests teachers should be encouraged and trained to put more effort in designing and offering suitable multimedia elements to enrich their materials, selfassessment test to make students feel more comfortable in terms of examination expectations, and

to design online activities for the students to enhance collaborative aspects in teaching.

The results obtained from "the general importance of specific e-learning elements" part of the survey indicated that students value the most the completeness, organization and design of educational materials, as well as teachers' online engagement, especially in good management of e-course, in regular 
communication and timely providing feedback. They do not perceive as much as important the online activities, communication to other students and discussions. When the comparison of "current state" and "general importance" for the specific e-learning elements is made, it seems that there is not much of discrepancy.

Through assessment of the general value of e-learning and its characteristic, participants best agree with the notion that most important is to have the access to teaching materials 24/7. Second best is that online materials are better suited to students' needs and that in general, having ecourse as addition to classroom teaching is helping them organizing their learning better and scoring better results.

As the general attitude towards online learning is considered, it is interesting that preferences for exclusively online and/or blended learning are dominant in a group of students having better average studying grades (A or B), as well as in a group having shorter studying experience (1-2 ys of studying). The same groups find the new communication channels (online discussion forums, mailing with teachers, assistants and colleagues within the online learning environment) important and useful. Moreover, they think that online educational materials and activities are better suited to students' needs and that they help them achieve the learning outcomes better. This result is an important signal to all instances supporting e-learning implementation.

The study outcomes generally suggest the need to enhance teachers' competencies for online teaching, particularly in acquiring successful tutoring methods and learners' support methods, and together with continuous and careful monitoring of learner's satisfaction we hope to ensure the success, feasibility and viability of online learning, as supporting educational tool in our university study programs.

Keywords: blended learning, higher education, learner's perspective, quality assurance, elearning acceptance.

\section{Introduction}

As education is becoming a ubiquitous service delivered anywhere and anytime over the global network, the higher education institutions, although campus oriented and without distance learners, try to implement elements of e-learning in traditional course delivery, in order to prepare their students, as well as the institution, for the future participation in education (Bonk, 2009; McCradie, 2003). In this process, there is also a hope that such changes will also induce some changes in traditional organization, planning and management of educational process.

University of Rijeka is one of the seven universities in Croatia, middle-sized with respect to number of students $(\approx 17500)$ and academics $(\approx 1100)$. As dynamic and change-oriented institution, in its policy documents in 2007 the University defined the strategic goals, particularly related to teaching and learning (T\&L) process and improvement of its overall quality. Thus the specific strategic objectives were set up: to increase the efficiency of studying, to modernize curricula and syllabi in the context of the Bologna declaration, to ensure the compatibility with international educational systems, to improve quality of teaching and learning through implementation of learning-outcomes oriented curricula, More over the goal was to increase the inter-university and international cooperation and to enhance the student and teacher mobility and to improve student services. Additionally motivated by the poor use of ICT in teaching and learning process, together with changes in curricula mandated by the Bologna process, the University management decided to enable the activities for e-learning implementation (Žuvić-Butorac \& Nebić, 2009). As University of Rijeka is campus based, the e-learning implementation was seen in the form of transforming pre-existing traditional classroom content delivery to combination of classroom and online 
delivery (blended learning), through setting up of e-courses which will support the classroom activities.

The process of implementing e-learning tools as a support for traditional classroom teaching started at the University of Rijeka at the beginning of 2008, following the strategic principles (Bates, 1999; Duderstadt, 2003; Ellis, 2007; Hanna, 2003) adapted to local environment (ŽuvićButorac, 2009). Since the time of the beginning of e-learning use and implementation of blended learning, the process has been constantly supported (through development of support services and education of teaching staff) and assessed for quality, but only from the institutional, teacher's and support services' perspective. Assuming that quality of the teaching and learning process is not something that is delivered to a student by e-learning provider, but rather constitutes a process of co-production between the learner and learning environment, we considered equally important to asses both the learner's perspective as well as learning environment aspects. In broader sense, the learning environment nowadays and particularly with the e-learning employed, is very complex and consists of many elements which contribute to its quality. It starts from the characteristics of the e-learning platform, technological and educational user's support, course design and T\&L methods and tutoring employed, all the way up to institutional support and management policies towards all participants in the educational process. Assessing the quality is therefore as much as important for the students, as for the university management, support services and the academics, as teachers, authors and tutors. Understanding that student's perception regarding e-learning is one of the most important steps in developing and implementing a successful e-learning environment (Keller \& Cernerud, 2002; Wagner \& Flannery, 2004), we conducted the study of student's perception and e-learning acceptance, presented here.

Three specific questions were addressed in the study: 1) student's perception of quality of already delivered e-courses, 2) level of importance for the specific elements of e-learning encountered, and 3) student's general attitude towards e-learning and their needs with respect to quality of course materials, communication and support of the learning process. Additionally, students were asked to assess the technical aspects of LMS use. The paper describes the results of the study and suggests possible implications for quality improvement.

\section{Research Methodology}

\section{Sample}

All the students at the University of Rijeka that were using MudRi e-learning system (Moodle open source learning management system) from February 2009 to February 2010 have been selected as a sample. The questionnaire is created as an online survey using the LimeSurvey open source software (Version 1.87). A request to take part in the survey and a direct link to it, with guaranteed privacy, has been sent via email to all the students in the MudRi user database. From the 1944 requests that were sent out, 361 questionnaires were received (19\% response), including 48 incomplete questionnaires which were eliminated from the further process (so the actual response rate was $16 \%$ ). As the survey was completed, the answers were automatically stored in the digital database, which was later used in the statistical data analysis. Data collection took place during January and February 2010.

The total number of the analyzed questionnaires is 313 . The age of the respondents is $22 \pm 4$ (median: 20 years of age, $10-90$ percentile range: $19-24$ years of age). According to gender, there are more male respondents (62\% male vs. $38 \%$ female respondents). Regarding the type of studies, $86 \%$ of the respondents are a part of university studies while $14 \%$ take part in professional studies. According to field of study, respondents are divided into three closely related categories: the group of studies that includes engineering, mathematics, natural sciences and medicine 
(ENGMATSCI, $40 \%$ of respondents), the group involving social sciences and humanities (SSH, $18 \%$ of respondents) and the group that includes information and communication technologies (ICT, $42 \%$ of the respondents). Regarding experience, the majority, $39 \%$ of students, are at their first year, $36 \%$ have been studying for 2 - 3 years, and $25 \%$ of respondents have been studying for more than 3 years. According to the number of previously used e-courses, $28 \%$ have used up to 2 e-courses, $44 \%$ have used $3-5$ e-courses, and $28 \%$ have used more than 5 e-courses. Regarding previous experience of e-learning, $57 \%$ of the respondents have one year experience, while $43 \%$ are more experienced users. Concerning success in studies, $16 \%$ of the respondents are excellent students (grade A), $37 \%$ are very good students (grade B), $40 \%$ are good (grade C) and $7 \%$ of the students are adequate (grade D).

\section{Methods}

Data are collected using an original questionnaire which is created for the purpose of this research. It is partly based on the experiences gained from the published researches (Bernard, Brauer, Abrami, \& Surkes, 2004; Davis, 1989; DeLone \& McLean, 2003; Poelmans, 2009) and partly on the experiences gained in the similar research conducted on the smaller sample including students from the Faculty of Philosophy at the University of Rijeka (Rončević, Ledić, \& Vrcelj, 2009). The questionnaire is divided into four parts. The first part includes general sociodemographic variables of the respondent (gender, age, size of place of residence, type of studies, year of study), the experience of e-learning (the number of attended e-courses, years of e-learning experience) and the preferences regarding the mode of courses (blended courses compared to direct, traditional and fully online courses). The second part of the questionnaire refers to the assessment of the existence of the certain e-learning elements in the used online courses, and the third part questions students' attitudes towards e-learning and the experience of using MudRi system. In the final, fourth part of the questionnaire, respondents assesses the personal importance of the existence of certain e-learning elements, i.e., what they do and do not find important and useful in an e-course.

The questionnaire defines 59 variables which are processed by appropriate statistical methods. The questions regarding e-course experience, attitudes towards e-learning and assessment of the importance of the e-learning elements were taken as dependent variables, and the independent variables are age and gender, size of place of residence, type and field of studies, experience of elearning, grade point average and preferences according to course mode (classroom/blended/online).

\section{Data Analysis}

Data are collected electronically and automatically stored into database. The software package SPSS 18.0 was used for statistical analysis. The categorical data were described by frequencies and percentages, while numerical data by means and standard deviations. Yates corrected Pearson Chi-square test was applied to determine statistically significant differences in contingency tables of frequencies. Numerical sets of data were compared using t-test or analysis of variance, where suitable. Comparison of specific groups in analysis of variance was performed using appropriate post-hoc tests (Scheffe test for homogeneous and Tamhane T2 for non-homogeneous variance). The level of statistical significance, $p$, was set at 0.05 in all analyses. To determine the factor structure (latent dimensions) for a set of variables defined in specific parts of the questionnaire, factor analysis was used. 


\section{Results}

\section{Sociodemographic Status of the Respondents and Student Profile}

Even though the first part of the questionnaire refers to the variables which are assumed to be independent, their potential relationship has been analyzed, so the conclusions could be interpreted correctly.

The field of study is, according to expectations, significantly related to the gender (Pearson Chisquare: $79.36, \mathrm{df}=2, \mathrm{p}<0.001$ ), where female respondents study social sciences and humanities in significantly higher number and male respondents study engineering, natural sciences and ICT. The number of e-courses that respondents use is closely connected to the field of study (Pearson Chi-square: $61.4, \mathrm{df}=4, \mathrm{p}<0.001$ ), where it can be seen that engineering, social sciences and ICT students have significantly higher number of e-courses than the students of social sciences and humanities. In addition, as anticipated, there is a significant correlation between the experience of e-learning and the field of study (Pearson Chi-square: 12.5, $\mathrm{df}=4, \mathrm{p}=0.002$ ), where ICT students have more extensive e-learning experience than others.

The attitude towards blended courses in comparison to direct, classroom and fully online courses has been analyzed. According to data, $77 \%$ of the respondents state that they prefer blended learning, $17 \%$ opt for exclusively classroom courses, while $7 \%$ find the fully online courses the optimal learning and teaching mode. Preference for certain mode of courses is significantly related to the success in studies (Pearson Chi-square: 12.63, $\mathrm{df}=6, \mathrm{p}=0.049$ ), where remarkably higher number of students with high grade point average (very good and excellent, B and A) support blended learning, while the supporters of traditional courses are graded somewhat lower (good, C). Interestingly, the preference for certain course mode (blended/classroom/online) is not related to any of the sociodemographic or student profile variables.

\section{Assessment of the Existence of E-Learning Elements in the E-Courses Using the MudRi System}

The second part of the questionnaire refers to the e-course users' assessment of the actual existence of certain e-learning elements in courses presented on university LMS, MudRi. The assessment was expressed by rating each statement on a five-point scale ranging from "entirely incorrect" (numerical score 1) to "entirely correct" (numerical score 5). The results are shown in the Table 1.

The statement rated as the most correct by $60 \%$ of the respondents is "E-course enabled Forum discussions". Interestingly, at the same time only $20 \%$ of the students involved in the online courses claim to have communicated with other colleagues from the group, which means that Forums, although set by the teacher, are used rarely. Other statements were regarded mostly as partly correct or entirely correct. Along these lines, $70 \%$ of the respondents find correct or mostly correct the statements about the learning materials being written in a clear and understanding manner, that they were delicately colored, had a simple standardized form, were coherent and well organized, that some educational activities were performed online and that the teacher edited the content and managed e-course activities regularly and often used the system for communication with students. Relating to the communication coming from students, $65 \%$ find it easy to communicate with teacher/assistant through e-course.

Implementation of features specific for online learning were rated as least correct or were rarely regarded as correct. For example, the implementation of the multimedia, self-assessment tests and 
mandatory and optional study material (in digital form) are assessed as good in 14 to $16 \%$ of the cases. These results are not surprising, regarding the fact that implementation of multimedia requires teachers to acquire specific knowledge and skills, and the creation of the self-assessment tests requires an extensive database of questions. Study material in digital form presents a particular problem since they are protected by copyright.

\section{Table 1. Actual existence of certain e-learning elements.}

\begin{tabular}{|c|c|c|c|c|c|c|c|c|}
\hline \multicolumn{2}{|c|}{ Statement } & \multicolumn{5}{|c|}{ Answers / \% } & \multirow{2}{*}{$\begin{array}{r}\text { mean } \\
3.9\end{array}$} & \multirow{2}{*}{$\begin{array}{l}\text { SD } \\
1.0\end{array}$} \\
\hline I1 & $\begin{array}{l}\text { The e-course provided all the materials } \\
\text { needed for achieving the expected learning } \\
\text { results. }\end{array}$ & 1 & 2 & 3 & $\begin{array}{l}4 \\
38\end{array}$ & 5 & & \\
\hline $\mathrm{I} 2$ & $\begin{array}{l}\text { Learning materials in the e-course were } \\
\text { written in a clear and understanding man- } \\
\text { ner, they were delicately colored, and had } \\
\text { a simple standardized form. }\end{array}$ & 1 & 4 & 21 & 38 & 37 & 4.1 & 0.9 \\
\hline $\mathrm{I} 3$ & $\begin{array}{l}\text { The learning materials and activities in the } \\
\text { e-course were well organized. }\end{array}$ & 0 & 7 & 20 & 41 & 32 & 4.0 & 0.9 \\
\hline $\mathrm{I} 4$ & $\begin{array}{l}\text { Multimedia (appropriate audio and video } \\
\text { content, animations, computer simulations, } \\
\text { etc.) was used in the e-course. }\end{array}$ & 19 & 26 & 23 & 16 & 16 & 2.9 & 1.4 \\
\hline I5 & $\begin{array}{l}\text { Some educational activities in the e-course } \\
\text { were conducted online (doing homework, } \\
\text { submitting the seminar papers, participat- } \\
\text { ing in discussions, etc.). }\end{array}$ & 5 & 8 & 15 & 31 & 40 & 3.9 & 1.2 \\
\hline I6 & $\begin{array}{l}\text { It was easy to communicate with } \\
\text { teacher/assistant through the e-course. }\end{array}$ & 4 & 7 & 24 & 30 & 35 & 3.9 & 1.1 \\
\hline I7 & $\begin{array}{l}\text { Through the e-course I communicated } \\
\text { with other colleagues from the group. }\end{array}$ & 18 & 17 & 25 & 21 & 20 & 3.1 & 1.4 \\
\hline I8 & E-course enabled Forum discussions. & 2 & 3 & 11 & 24 & 60 & 4.4 & 0.9 \\
\hline I9 & $\begin{array}{l}\text { E-course provided ways to test knowledge } \\
\text { through self-assessment. }\end{array}$ & 23 & 20 & 19 & 24 & 15 & 2.9 & 1.4 \\
\hline I10 & $\begin{array}{l}\text { E-course provided mandatory and optional } \\
\text { study material in digital form. }\end{array}$ & 14 & 23 & 27 & 22 & 14 & 3.0 & 1.3 \\
\hline I11 & $\begin{array}{l}\text { E-course teacher edited content and man- } \\
\text { aged e-course activities regularly. }\end{array}$ & 1 & 5 & 20 & 35 & 40 & 4.1 & 0.9 \\
\hline I12 & $\begin{array}{l}\text { E-course teacher used the system to com- } \\
\text { municate with students regularly. }\end{array}$ & 3 & 7 & 19 & 35 & 36 & 3.9 & 1.0 \\
\hline I13 & $\begin{array}{l}\text { I regularly received feedback about my } \\
\text { work from e-course teacher. }\end{array}$ & 2 & 7 & 25 & 32 & 34 & 3.9 & 1.0 \\
\hline
\end{tabular}

All the values of variables I1 to I13 have been tested for the differences between groups defined by independent variables. We will single out only the interesting results. In contrast to our expectations, the results show that the students of the SSH group of studies rate implementation of the multimedia, online activities and the teacher's regularity in editing content and online activities 
higher than other students. SSH students assess implementation of multimedia (3.3 $\pm 1.4 \mathrm{vs}$. $3.0 \pm 1.3$ ENGMATSCI and 2.5 \pm 1.2 ICT students, $\mathrm{F}=10.65, \mathrm{p}<0.001)$ and e-course online activities (4.4 \pm 0.9 vs. $3.8 \pm 1.3$ ENGMATSCI and $3.9 \pm 0.9$ ICT students, $\mathrm{F}=6.58, \mathrm{p}=0.002)$ with a significantly higher score than other students. The teacher's regularity in editing content and activities in the e-course is rated significantly lower by ICT students ( $3.9 \pm 0.9$ vs. $4.1 \pm 0.9$ ENGMATSCI and $4.3 \pm 0.9 \mathrm{SSH}$ students, $\mathrm{F}=3.49 \mathrm{p}=0.032$ ). Equally interesting is the result regarding the differences in rating experiences in comparison with the attitude towards the course, i.e., the preference for the course mode. Different from online course supporters and traditional classroom supporters, the students preferring blended learning describe e-learning materials as coherent and sufficient for achieving the expected learning results. On the other hand, the respondents with the attitude "classroom courses are the optimal ones" give lower scores for the organization of the learning materials and activities, the experiences with all aspects of communication, and to the teacher's involvement in the e-course (Table 2.).

\begin{tabular}{|c|c|c|c|c|c|c|c|c|c|}
\hline \multirow{3}{*}{\multicolumn{2}{|c|}{ Statement }} & \multicolumn{6}{|c|}{ I prefer... } & \multirow{2}{*}{\multicolumn{2}{|c|}{ ANOVA test }} \\
\hline & & \multicolumn{2}{|c|}{ Blended } & \multicolumn{2}{|c|}{ Online } & \multicolumn{2}{|c|}{ Classroom } & & \\
\hline & & mean & SD & mean & SD & mean & SD & $\mathrm{F}$ & $\mathrm{p}$ \\
\hline I1 & $\begin{array}{l}\text { The e-course provided all the materi- } \\
\text { als needed for achieving the expected } \\
\text { learning results. }\end{array}$ & 4.0 & 0.9 & 3.7 & 1.0 & 3.6 & 1.1 & 5.03 & 0.007 \\
\hline I3 & $\begin{array}{l}\text { The learning materials and activities in } \\
\text { the e-course were well organized. }\end{array}$ & 4.1 & 0.9 & 4.0 & 1.0 & 3.5 & 0.9 & 8.76 & $<0.001$ \\
\hline I6 & $\begin{array}{l}\text { It was easy to communicate with } \\
\text { teacher/assistant through the e-course. }\end{array}$ & 4.0 & 1.1 & 4.2 & 1.1 & 3.2 & 1.1 & 11.66 & $<0.001$ \\
\hline I7 & $\begin{array}{l}\text { Through the e-course I communicated } \\
\text { with other colleagues from the group. }\end{array}$ & 3.2 & 1.3 & 3.4 & 1.6 & 2.4 & 1.3 & 6.99 & 0.001 \\
\hline I8 & E-course enabled Forum discussions. & 4.4 & 0.9 & 4.7 & 0.7 & 4.0 & 1.0 & 4.84 & 0.009 \\
\hline I11 & $\begin{array}{l}\text { E-course teacher edited content and } \\
\text { managed e-course activities regularly. }\end{array}$ & 4.1 & 0.9 & 4.1 & 0.9 & 3.8 & 0.9 & 3.30 & 0.038 \\
\hline I12 & $\begin{array}{l}\text { E-course teacher used the system to } \\
\text { communicate with students regularly. }\end{array}$ & 4.0 & 1.0 & 4.0 & 1.0 & 3.6 & 1.0 & 3.30 & 0.038 \\
\hline I13 & $\begin{array}{l}\text { I regularly received feedback about } \\
\text { my work from e-course teacher. }\end{array}$ & 4.0 & 1.0 & 4.1 & 0.9 & 3.5 & 1.0 & 4.31 & 0.014 \\
\hline
\end{tabular}

\section{The Importance of the Existence of E-Learning Elements in E-Courses}

This part of the questionnaire determines the importance of e-learning elements in e-courses for the students. As opposed to the assessment of actually present elements, students value the general importance of the same elements more (Table 3. vs. Table 1.). More than $90 \%$ of the respondents find important or extremely important all the statements relating to the organization, coherence and clarity of the learning materials (S1, S2, S3) and statements relating to the teacher's activities and editing (S11, S12, S13). They give a lower score for the importance of the existence of online activities, knowledge self-assessment tests and communication with the teacher using the system (S5, S6 and S9). The least important for the students is the existence of the multimedia 
elements (S4), forum discussions (S8) and the ability to communicate to their colleagues through the e-course (S7).

Table 3. Importance of the existence of certain e-course elements in general.

\begin{tabular}{|c|c|c|c|c|c|c|c|c|}
\hline \multirow{2}{*}{\multicolumn{2}{|c|}{ Statement }} & \multicolumn{5}{|c|}{ Answer / \% } & \multirow{3}{*}{$\begin{array}{l}\text { mean } \\
4.6\end{array}$} & \multirow{3}{*}{$\begin{array}{l}\text { SD } \\
0.7\end{array}$} \\
\hline & & \multirow{2}{*}{1} & \multirow{2}{*}{2} & \multirow{2}{*}{3} & \multirow{2}{*}{4} & \multirow{2}{*}{5} & & \\
\hline S1 & $\begin{array}{l}\text { It is important to me that e-course provides all the } \\
\text { materials needed for achieving the expected learning } \\
\text { results. }\end{array}$ & & & & & & & \\
\hline S2 & $\begin{array}{l}\text { It is important to me that learning materials in the e- } \\
\text { course are written in a clear and understanding man- } \\
\text { ner, that they are delicately colored, and have a sim- } \\
\text { ple standardized form. }\end{array}$ & 0 & 1 & 9 & 26 & 64 & 4.5 & 0.7 \\
\hline S3 & $\begin{array}{l}\text { It is important to me that learning materials and ac- } \\
\text { tivities in the e-course are well organized. }\end{array}$ & 0 & 1 & 5 & 24 & 69 & 4.6 & 0.7 \\
\hline S4 & $\begin{array}{l}\text { It is important to me that multimedia (appropriate } \\
\text { audio and video content, animations, computer simu- } \\
\text { lations, etc.) is used in the e-course. }\end{array}$ & 5 & 10 & 28 & 27 & 30 & 3.7 & 1.2 \\
\hline S5 & $\begin{array}{l}\text { It is important to me that some educational activities } \\
\text { in the e-course are conducted online (doing home- } \\
\text { work, submitting the seminar papers, participating in } \\
\text { discussions, etc.). }\end{array}$ & 3 & 5 & 16 & 31 & 45 & 4.1 & 1.1 \\
\hline S6 & $\begin{array}{l}\text { It is important to me that it is easy to communicate } \\
\text { with teacher/assistant through the e-course. }\end{array}$ & 5 & 7 & 23 & 30 & 34 & 3.8 & 1.1 \\
\hline S7 & $\begin{array}{l}\text { It is important to me that through the e-course I } \\
\text { communicate with other colleagues from the group. }\end{array}$ & 9 & 14 & 25 & 25 & 26 & 3.4 & 1.4 \\
\hline S8 & $\begin{array}{l}\text { It is important to me that e-course enables Forum } \\
\text { discussions. }\end{array}$ & 6 & 11 & 26 & 28 & 29 & 3.6 & 1.2 \\
\hline S9 & $\begin{array}{l}\text { It is important to me that e-course provides ways to } \\
\text { test knowledge through self-assessment. }\end{array}$ & 5 & 5 & 23 & 28 & 40 & 3.9 & 1.1 \\
\hline S10 & $\begin{array}{l}\text { It is important to me that e-course provides manda- } \\
\text { tory and optional study material in digital form. }\end{array}$ & 1 & 3 & 11 & 24 & 61 & 4.4 & 0.9 \\
\hline S11 & $\begin{array}{l}\text { It is important to me that e-course teacher edits con- } \\
\text { tent and manages e-course activities regularly. }\end{array}$ & 0 & 0 & 4 & 19 & 77 & 4.7 & 0.6 \\
\hline $\mathrm{S} 12$ & $\begin{array}{l}\text { It is important to me that e-course teacher uses the } \\
\text { system to communicate with students regularly. }\end{array}$ & 1 & 2 & 11 & 29 & 58 & 4.4 & 0.8 \\
\hline S13 & $\begin{array}{l}\text { It is important to me that I regularly receive feedback } \\
\text { about my work from e-course teacher. }\end{array}$ & 0 & 0 & 9 & 22 & 69 & 4.6 & 0.7 \\
\hline
\end{tabular}

All the statements in this part of the questionnaire were analyzed considering groups defined by independent variables. Thus, female respondents give significantly higher scores for the statements describing the coherence and the organization of learning materials as well as receiving feedback from the teacher (to all statements $4.7 \pm 0.6$ vs. $4.5 \pm 0.7$ with male respondents, t-test, $\mathrm{p}<0.010$ ). According to field of study, ENGMATSCI students find good organization of the learning materials less important than other students ( $4.5 \pm 0.8$ vs. $4.7 \pm 0.6$ with ICT and $4.8 \pm 0.5$ 
with SSH students, ANOVA, $\mathrm{F}=3.71, \mathrm{p}=0.026)$, as well as the existence of multimedia $(3.5 \pm 1.2$ vs. $3.7 \pm 1.1$ with ICT and $4.1 \pm 1.0$ with SSH students, ANOVA, $F=4.65, \mathrm{p}=0.010$ ). Students with shorter study experience and e-course use experience give significantly higher score for the ability to communicate with other colleagues from the group $(3.7 \pm 1.1$ with first year students vs. $3.2 \pm 1.3$ with second year students and older, ANOVA, $F=6.19, \mathrm{p}=0.002)$ and they value the ability of forum discussions more (3.9 \pm 1.0 with first year students vs. $3.4 \pm 1.3$ with second year students and older, ANOVA, $\mathrm{F}=5.84, \mathrm{p}=0.003$ ). Observing the differences in rating in relation to the attitude towards the course (preferences for blended/online/classroom), students opting for traditional classroom courses give significantly lower scores for a large number of statements (Table 4.): the coherence of the learning material, the existence of the online activities, communication with other colleagues and the teacher, Forum discussions and teacher's involvement (regularity of content and activity editing, communication with students, providing feedback).

Table 4. Importance of certain e-course elements in relation to the course mode preference.

\begin{tabular}{|c|c|c|c|c|c|c|c|c|c|}
\hline \multirow{3}{*}{\multicolumn{2}{|c|}{ Statement: " It is important to me that:" }} & \multicolumn{6}{|c|}{ I prefer... } & \multirow{2}{*}{\multicolumn{2}{|c|}{ ANOVA test }} \\
\hline & & \multicolumn{2}{|c|}{ Blended } & \multicolumn{2}{|c|}{ Online } & \multicolumn{2}{|c|}{ Classroom } & & \\
\hline & & mean & SD & mean & SD & mean & SD & $\bar{F}$ & $\mathrm{p}$ \\
\hline S1 & $\begin{array}{l}\text { E-course provides all the materials } \\
\text { needed for achieving the expected } \\
\text { learning results. }\end{array}$ & 4.6 & 0.6 & 4.8 & 0.5 & 4.3 & 0.9 & 8.1 & $<0.001$ \\
\hline S5 & $\begin{array}{l}\text { Some educational activities in the e- } \\
\text { course are conducted online. }\end{array}$ & 4.3 & 0.9 & 4.4 & 1.2 & 3.1 & 1.1 & 37.7 & $<0.001$ \\
\hline S6 & $\begin{array}{l}\text { It is easy to communicate with } \\
\text { teacher/assistant through the e-course. }\end{array}$ & 3.9 & 1.1 & 4.3 & 0.9 & 3.0 & 1.1 & 16.7 & $<0.001$ \\
\hline S7 & $\begin{array}{l}\text { Through the e-course I communicate } \\
\text { with other colleagues from the group. }\end{array}$ & 3.5 & 1.3 & 4.0 & 1.2 & 2.9 & 1.2 & 7.7 & 0.001 \\
\hline S8. & E-course enables Forum discussions. & 3.7 & 1.2 & 4.2 & 0.7 & 3.0 & 1.1 & 10.6 & $<0.001$ \\
\hline S9 & $\begin{array}{l}\text { E-course provides ways to test knowl- } \\
\text { edge through self-assessment. }\end{array}$ & 4.0 & 1.1 & 4.2 & 1.1 & 3.4 & 1.1 & 7.3 & 0.001 \\
\hline S11 & $\begin{array}{l}\text { E-course teacher edits content and } \\
\text { manages e-course activities regularly. }\end{array}$ & 4.8 & 0.9 & 4.8 & 0.6 & 4.5 & 0.8 & 6.2 & 0.002 \\
\hline $\mathrm{S} 12$ & $\begin{array}{l}\text { E-course teacher uses the system to } \\
\text { communicate with students regularly. }\end{array}$ & 4.5 & 0.5 & 4.7 & 0.5 & 4.1 & 0.8 & 5.7 & 0.004 \\
\hline S13 & $\begin{array}{l}\text { I regularly receive feedback about my } \\
\text { work from e-course teacher. }\end{array}$ & 4.6 & 0.8 & 4.8 & 0.7 & 4.4 & 1.0 & 4.2 & 0.015 \\
\hline
\end{tabular}

\section{Students' Attitudes towards E-Learning and E-Courses in General}

The final part of the questionnaire refers to the students' attitudes towards e-learning and ecourses in general (Table 5.). Bearing in mind that all of the courses using MudRi system at the University of Rijeka are realized as blended learning mode, these attitudes as well should be interpreted through the aforementioned prism.

The statement students agree with the most is the attitude towards the high importance and utility of having unlimited access to all materials ( $88 \%$ correct or entirely correct). Somewhat lower in percentage, but still highly rated, are the attitudes that the learning materials in e-courses are more 
suitable for the students (66\% correct and entirely correct), that e-course contributes to better learning organization ( $56 \%$ correct and entirely correct), and the attitude that the blended course mode produces better results ( $53 \%$ correct and entirely correct). It is also important to notice that $56 \%$ of the respondents find face-to-face contact with the teacher important to encourage their learning process. However, a large number of students (one third to one fourth of the students) cannot rate the attitudes (except S17); for example, more than $30 \%$ cannot assess whether they achieve better results in blended mode course, their level of activity in e-courses and their communication with teacher and other students. These results indicate insufficient assessment of the role of the teacher and of the students' opinion which course modes are most suitable for them, i.e., which modes produce the best results, by a large number of students. Almost $50 \%$ of the respondents state that the communication methods in the e-course are mostly unnecessary or ineffective. Thus, respondents often find discussions more successful in the classroom than in ecourse $(23 \%)$, it is easier for them to communicate with teacher/assistant in person $(23 \%)$, and rarely rate the e-course communication about learning topics, content and activities with other colleagues as better $(7 \%)$.

\section{Table 5. Students' attitudes towards e-courses in general.}

\begin{tabular}{|c|c|c|c|c|c|c|c|c|}
\hline \multirow{2}{*}{\multicolumn{2}{|c|}{ Statement }} & \multicolumn{5}{|c|}{ Answer / \% } & \multirow{3}{*}{$\begin{array}{c}\text { me } \\
\text { an }\end{array}$} & \multirow{3}{*}{$\begin{array}{l}\text { SD } \\
1.1\end{array}$} \\
\hline & & \multirow{2}{*}{$\frac{1}{5}$} & \multirow{2}{*}{$\begin{array}{c}2 \\
12\end{array}$} & \multirow{2}{*}{3} & \multirow{2}{*}{$\begin{array}{c}4 \\
36\end{array}$} & \multirow{2}{*}{$\begin{array}{c}5 \\
20\end{array}$} & & \\
\hline $\begin{array}{l}\mathrm{S} 1 \\
4\end{array}$ & $\begin{array}{l}\text { E-course helps me to organize my learning process } \\
\text { better. }\end{array}$ & & & & & & & \\
\hline $\begin{array}{l}\text { S1 } \\
5\end{array}$ & $\begin{array}{l}\text { I achieve better results in the courses which combine } \\
\text { online and classroom mode of learning. }\end{array}$ & 8 & 7 & 33 & 31 & 22 & 3.5 & 1.1 \\
\hline $\begin{array}{l}\text { S1 } \\
6\end{array}$ & $\begin{array}{l}\text { In e-courses I participate more actively and complete } \\
\text { my assignments more regularly than in exclusively } \\
\text { classroom courses. }\end{array}$ & 15 & 10 & 32 & 25 & 18 & 3.2 & 1.3 \\
\hline $\begin{array}{l}\text { S1 } \\
7\end{array}$ & $\begin{array}{l}\text { It is important and useful to have unlimited access to } \\
\text { all materials. }\end{array}$ & 2 & 2 & 8 & 22 & 66 & 4.5 & 0.9 \\
\hline $\begin{array}{l}\text { S1 } \\
8\end{array}$ & $\begin{array}{l}\text { E-course learning materials are more suitable for stu- } \\
\text { dents' needs. }\end{array}$ & 3 & 7 & 25 & 44 & 22 & 3.7 & 1.0 \\
\hline $\begin{array}{l}\text { S1 } \\
9\end{array}$ & $\begin{array}{l}\text { Discussions in e-course are more successful than in } \\
\text { the classroom. }\end{array}$ & 23 & 20 & 27 & 19 & 11 & 2.8 & 1.3 \\
\hline $\begin{array}{l}\mathrm{S} 2 \\
0\end{array}$ & $\begin{array}{l}\text { Through e-course I communicate better with other } \\
\text { students about the learning topics, content and activi- } \\
\text { ties. }\end{array}$ & 26 & 23 & 26 & 19 & 7 & 2.6 & 1.2 \\
\hline $\begin{array}{l}\mathrm{S} 2 \\
1\end{array}$ & $\begin{array}{l}\text { E-courses provide easier communication with } \\
\text { teacher/assistant than it is in person. }\end{array}$ & 23 & 17 & 31 & 18 & 11 & 2.8 & 1.3 \\
\hline $\begin{array}{l}\mathrm{S} 2 \\
2\end{array}$ & $\begin{array}{l}\text { Face-to-face contact with my teacher is fairly impor- } \\
\text { tant to encourage the learning process. }\end{array}$ & 9 & 10 & 25 & 24 & 32 & 3.6 & 1.3 \\
\hline $\begin{array}{l}\mathrm{S} 2 \\
3\end{array}$ & $\begin{array}{l}\text { It bothers me that in e-learning I am distracted by } \\
\text { other online activities (video games, social networks, } \\
\text { etc.). }\end{array}$ & 18 & 19 & 22 & 22 & 19 & 3.1 & 1.4 \\
\hline
\end{tabular}

Scores for the attitudes were analyzed in relation to the groups of respondents defined by certain independent variables. Significant differences in rating are evident only in relation to study experience (years of studying) and attitude towards the course, and there is no significant differ- 
ences according to gender or field of study in none of the statements in this part of the questionnaire. Students with less experience (first year students) rate specific communication channels of the e-course significantly higher than more experienced students; they find e-discussions more successful than the ones done in the classroom ( $3.0 \pm 1.2$ vs. $2.5 \pm 1.3$, ANOVA, $F=5.1, p=0.007)$, they also find communication with other students better (2.9 \pm 1.2 vs. $2.3 \pm 1.2$, ANOVA, $\mathrm{F}=6.24$, $\mathrm{p}=0.002)$, and they think the communication with the teacher is easier ( $3.0 \pm 1.2$ vs. $2.6 \pm 1.3$, ANOVA, $\mathrm{F}=3.28, \mathrm{p}=0.039)$. As in previous analysis, the attitude towards course significantly influences the scores for e-learning attitudes. In all of the statements in this part of the questionnaire there are statistically significant differences in rating in relation to the preferred course mode (Table 6.). With the exception of the statements S22 and S23, which describe potential disruptions in e-learning (the lack of face-to-face contact with the teacher and distraction by other online content), the students who prefer traditional course mode rate the attitudes towards elearning remarkably lower than the students preferring blended or fully online course mode.

Table 6. Students' attitudes towards e-learning in relation to the course mode preference.

\begin{tabular}{|c|c|c|c|c|c|c|c|c|c|}
\hline \multirow{3}{*}{\multicolumn{2}{|c|}{ Statement }} & \multicolumn{6}{|c|}{ I prefer... } & \multirow{2}{*}{\multicolumn{2}{|c|}{ ANOVA }} \\
\hline & & \multicolumn{2}{|c|}{ Blended } & \multicolumn{2}{|c|}{ Online } & \multicolumn{2}{|c|}{ Classroom } & & \\
\hline & & mean & SD & mean & SD & mean & SD & $\bar{F}$ & $\mathrm{p}$ \\
\hline S14 & $\begin{array}{l}\text { E-course helps me to organize } \\
\text { my study process better. }\end{array}$ & 3.6 & 1.1 & 4.0 & 1.1 & 2.8 & 1.1 & 13.55 & $<0.001$ \\
\hline S15 & $\begin{array}{l}\text { I achieve better results in the } \\
\text { courses which combine online } \\
\text { and classroom mode of learning. }\end{array}$ & 3.6 & 1.1 & 4.1 & 0.9 & 2.7 & 1.0 & 21.97 & $<0.001$ \\
\hline S16 & $\begin{array}{l}\text { In e-courses I participate more } \\
\text { actively and complete my as- } \\
\text { signments more regularly than in } \\
\text { exclusively classroom courses. }\end{array}$ & 3.3 & 1.2 & 4.0 & 1.0 & 2.3 & 1.2 & 21.89 & $<0.001$ \\
\hline S17 & $\begin{array}{l}\text { It is important and useful to have } \\
\text { unlimited access to all the mate- } \\
\text { rials. }\end{array}$ & 4.6 & 0.8 & 4.7 & 0.6 & 3.9 & 1.0 & 14.16 & $<0.001$ \\
\hline S18 & $\begin{array}{l}\text { E-course learning materials are } \\
\text { more suitable for students' } \\
\text { needs. }\end{array}$ & 3.8 & 0.9 & 4.2 & 0.8 & 3.2 & 1.0 & 14.07 & $<0.001$ \\
\hline S19 & $\begin{array}{l}\text { Discussions in e-course are more } \\
\text { successful than in the classroom. }\end{array}$ & 2.8 & 1.3 & 3.7 & 1.0 & 2.1 & 1.1 & 14.67 & $<0.001$ \\
\hline S20 & $\begin{array}{l}\text { Through e-course I communi- } \\
\text { cate better with other students } \\
\text { about the learning topics, con- } \\
\text { tent and activities. }\end{array}$ & 2.6 & 1.2 & 3.4 & 1.3 & 2.1 & 1.0 & 9.52 & $<0.001$ \\
\hline S21 & $\begin{array}{l}\text { E-courses provide easier com- } \\
\text { munication with teacher / assis- } \\
\text { tant than it is in person. }\end{array}$ & 2.8 & 1.2 & 3.8 & 1.3 & 2.0 & 1.1 & 16.62 & $<0.001$ \\
\hline S22 & $\begin{array}{l}\text { Face-to-face contact with my } \\
\text { teacher is fairly important to } \\
\text { encourage the learning process. }\end{array}$ & 3.6 & 1.3 & 2.6 & 1.2 & 4.2 & 1.1 & 13.97 & $<0.001$ \\
\hline S23 & $\begin{array}{l}\text { It bothers me that in e-learning I } \\
\text { am distracted by other online } \\
\text { activities (video games, social } \\
\text { networks, listening to music, } \\
\text { etc.). }\end{array}$ & 3.0 & 1.4 & 2.7 & 1.4 & 3.5 & 1.3 & 3.39 & 0.035 \\
\hline
\end{tabular}




\section{Working with the MudRi system}

Some of the questions in the survey referred to the students' experiences of working with the MudRi system, and their personal assessment of the ease of working online was required, as well as of the system's suitability for the students' needs (Table 7.).

Table 7. Students' experiences of working with the MudRi system.

\begin{tabular}{|c|c|c|c|c|c|c|c|c|}
\hline \multirow{2}{*}{\multicolumn{2}{|c|}{ Statement }} & \multicolumn{5}{|c|}{ Answer / \% } & \multirow{3}{*}{$\begin{array}{c}\text { mean } \\
4.7\end{array}$} & \multirow{3}{*}{\begin{tabular}{|l} 
SD \\
0.7
\end{tabular}} \\
\hline & & \multirow{2}{*}{$\begin{array}{l}1 \\
1\end{array}$} & \multirow{2}{*}{$\begin{array}{l}2 \\
2\end{array}$} & \multirow{2}{*}{$\begin{array}{l}3 \\
7\end{array}$} & \multirow{2}{*}{$\begin{array}{c}4 \\
13\end{array}$} & \multirow{2}{*}{$\begin{array}{c}5 \\
78\end{array}$} & & \\
\hline SUS 1 & $\begin{array}{l}\text { My computer literacy is sufficient for the successful } \\
\text { use of e-course and working with MudRi system. }\end{array}$ & & & & & & & \\
\hline SUS 2. & $\begin{array}{l}\text { Often I have problem accessing MudRI and my e- } \\
\text { courses }\end{array}$ & 50 & 20 & 0 & 20 & 10 & 2.2 & 1.1 \\
\hline SUS 3 & Often I have problems opening files on MudRI. & 55 & 21 & 12 & 7 & 5 & 1.9 & 1.2 \\
\hline SUS 4 & $\begin{array}{l}\text { When I encounter a technical problem, I know I can } \\
\text { contact the MudRi administrator. }\end{array}$ & 14 & 13 & 29 & 20 & 24 & 3.3 & 1.3 \\
\hline SUS 5 & I like the interface of the MudRi system. & 7 & 7 & 33 & 35 & 19 & 3.5 & 1.1 \\
\hline SUS 6 & $\begin{array}{l}\text { The navigation in the MudRi system is intuitive and } \\
\text { easy. }\end{array}$ & 2 & 7 & 15 & 37 & 40 & 4.1 & 1.0 \\
\hline
\end{tabular}

A large number of students (over $90 \%$ "mostly correct" and "entirely correct" answers) think they possess enough computer literacy to successfully use the MudRi system. Students mostly like the system's interface (54\%), and $77 \%$ of the respondents find the navigation easy for the user. The users should be better informed about the ability to contact the MudRi administrator in case of technical problems (less than half of the respondents are aware of this possibility). Majority of the students have no problems accessing the MudRi system ( $70 \%$ of the respondents never had any problems) nor opening files in the system $(76 \%)$.

\section{Factor Analysis: The Actual Existence of E-Learning Elements in the Used E-Courses}

Latent dimensions were determined by factor analysis $(\mathrm{KMO}=0,824$, Bartlett's sphere test is statistically significant at the level of $\mathrm{p}<0.001$ ) under the component model using GK criterion for limiting factor extraction (higher than 1), basic solution was transformed into orthogonal varimax position. In the final factor model there were 11 variables, three factors were obtained which interpret $57 \%$ of the total variance, the first factor interprets $34 \%$, the second one $12.72 \%$ and the third one interprets $10.28 \%$ of the total variance. Two statements (5 and 12 , see Table 1.) were left out of the analysis, because they did not meet the requirements of the Thurston principle of the simple structure (variable is measuring the subject properly if the variable saturations in other dimensions are particularly low).

The first factor consists of five statements: 1, 2, 3, 11 and 13 (Table 8.) and interprets $34 \%$ of the total variance. The statements refer to the organization, clarity, order, existence of the needed materials as well as to other dimensions of the quality learning material. Furthermore, there are statements referring to the role of the teacher, and since regular editing of the materials and the feedback are also part of this factor, it is called "Learning materials and teacher". 
The second factor includes three statements: 6,7 and 8 , and interprets $12.7 \%$ of the total variance. The statements refer to the possible and simplified communication with other students and teacher/assistant in e-courses, especially through Forums, therefore this factor is called "Online communication and activities".

The third factor consists of three statements as well: 4, 9 and 10, and interprets $10.3 \%$ of the total variance. The statements refer to the additional value in e-courses which requires great preparation, skills and competences from the teachers. It concerns the availability of mandatory and optional study material in digital form, knowledge self-assessment tests and the use of multimedia. This factor is called "E-help in learning".

Cronbach reliability coefficient is calculated for every set of variables in a certain factor. In the first factor, the Alpha coefficient was 0.775 (4 variables). In the second factor, the Alpha coefficient was 0.634 ( 3 variables). In the third factor, the Alpha coefficient was 0.570 ( 3 variables). In general, we can say that these scales are a reliable set of features.

Among the factors there is a statistically significant difference in scores (factor "Help in elearning" has significantly lower score than the rest). It can be concluded from the rating that the elements of the factor "Help in e-learning" are not very present in the e-courses (self-assessment tests, e-literature and multimedia).

Table 8. The structure of latent dimensions: the actual existence of certain e-learning elements.

\begin{tabular}{|c|c|c|c|c|c|c|c|c|c|}
\hline \multirow[t]{2}{*}{$\begin{array}{l}\text { Factor } \\
\text { title }\end{array}$} & \multicolumn{2}{|c|}{ Statement } & \multicolumn{3}{|c|}{ Factor } & \multirow{3}{*}{$\begin{array}{c}\text { mean } \\
4.0\end{array}$} & \multirow{3}{*}{$\begin{array}{l}\text { SD } \\
0.9\end{array}$} & \multirow[t]{2}{*}{$\begin{array}{c}\text { Factor } \\
\text { mean }\end{array}$} & \multirow{2}{*}{$\begin{array}{l}\text { Fac- } \\
\text { tor } \\
\text { SD }\end{array}$} \\
\hline & & & 1 & 2 & 3 & & & & \\
\hline \multirow{5}{*}{ 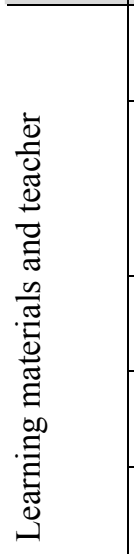 } & I3 & $\begin{array}{l}\text { The learning materials and activities in the e- } \\
\text { course were well organized. }\end{array}$ & 0.79 & & & & & \multirow[b]{2}{*}{4.0} & \multirow[b]{2}{*}{0.9} \\
\hline & $\mathrm{I} 2$ & $\begin{array}{l}\text { Learning materials in the e-course were written } \\
\text { in a clear and understanding manner, they were } \\
\text { delicately colored, and had a simple standard- } \\
\text { ized form. }\end{array}$ & 0.79 & & & 4.1 & 0.9 & & \\
\hline & I1 & $\begin{array}{l}\text { The e-course provided all the materials needed } \\
\text { for achieving the expected learning results. }\end{array}$ & 0.75 & & & 3.9 & 1.0 & & \\
\hline & I11 & $\begin{array}{l}\text { E-course teacher edited content and managed } \\
\text { e-course activities regularly. }\end{array}$ & 0.56 & & & 4.1 & 0.9 & & \\
\hline & I13 & $\begin{array}{l}\text { I regularly received feedback about my work } \\
\text { from e-course teacher. }\end{array}$ & 0.54 & & & 3.9 & 1.0 & & \\
\hline \multirow{3}{*}{ 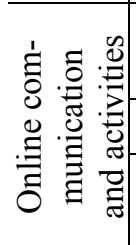 } & I7 & $\begin{array}{l}\text { Through the e-course I communicated with } \\
\text { other colleagues from the group. }\end{array}$ & & 0.74 & & 3.1 & 1.4 & \multirow{3}{*}{3.8} & \multirow{3}{*}{1.3} \\
\hline & I8 & E-course enabled Forum discussions. & & 0.71 & & 4.4 & 0.9 & & \\
\hline & I6 & $\begin{array}{l}\text { It was easy to communicate with } \\
\text { teacher/assistant through the e-course. }\end{array}$ & 0.38 & 0.70 & & 3.8 & 1.1 & & \\
\hline \multirow{3}{*}{ 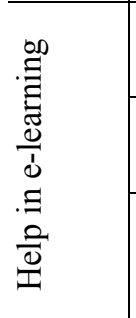 } & $\mathrm{I} 10$ & $\begin{array}{l}\text { E-course provided mandatory and optional } \\
\text { study material in digital form. }\end{array}$ & & & 0.82 & 3.0 & 1.3 & \multirow{3}{*}{2.9} & \multirow{3}{*}{1.3} \\
\hline & I9 & $\begin{array}{l}\text { E-course provided ways to test knowledge } \\
\text { through self-assessment. }\end{array}$ & & & 0.71 & 2.9 & 1.4 & & \\
\hline & I4 & $\begin{array}{l}\text { Multimedia (appropriate audio and video con- } \\
\text { tent, animations, computer simulations, etc.) } \\
\text { was used in the e-course. }\end{array}$ & 0.36 & & 0.55 & 2.9 & 1.3 & & \\
\hline
\end{tabular}


Scores for certain factors were also analyzed according to the groups of students defined by independent variables. In relation to gender, there are significant differences only in the factor "Learning materials and teacher", where female respondents give significantly higher score (4.1 \pm 0.9 vs. $3.9 \pm 0.9, \mathrm{t}=4.81, \mathrm{p}<0.001)$. According to field of study, there is also a significant difference only in the factor "Learning materials and teacher", where SSH students give significantly higher score than the other groups $(4.2 \pm 0.9$ vs. $3.9 \pm 0.9$ ICT students and $4.0 \pm 0.9$ ENGMATSCI students, ANOVA, $F=6.43, p=0.001$ ). Regarding study experience, the differences exist only in the factor "Online communication and activities", where least experienced students give significantly higher scores $(4.0 \pm 1.2$ with first year students, in contrast to $3.6 \pm 1.3$ with older students, $\mathrm{F}=8.85$, $\mathrm{p}<0.001)$. Regarding e-learning experience, the difference in scores occurs in two factors "Online communication and activities" and "E-help in learning". Thus, the inexperienced e-course users (up to one year) give significantly higher scores for the factor "Online communication and activities" ( $3.9 \pm 1.3$ vs. $3.6 \pm 1.3$ with more experienced users, $\mathrm{t}=2.76, \mathrm{p}=0.006$ ), as well as the factor "ehelp in learning" ( $3.0 \pm 1.3$ vs. $2.8 \pm 1.3, \mathrm{t}=1.97, \mathrm{p}=0.049)$. The attitude towards courses differentiates respondents according to the rating of the factor "Learning materials and teacher" and "Online communication and activities". Thus, the students who prefer traditional classroom courses give significantly lower scores than others for both factors (for "Learning materials and teacher" $3.7 \pm 1.0$ vs. $4.0 \pm 0.9$ online and $4.1 \pm 0.9$ blended courses, $F=18.11, \mathrm{p}<0.001$, and for "Online communication and activities" $3.2 \pm 1.3$ vs. $3.8 \pm 1.2$ online and $4.1 \pm 1.3$ blended courses, $\mathrm{F}=18.18, \mathrm{p}<0.001)$.

Students rate factor 1 differently according to their grade point average, thus the finest students give the highest scores, while the less good students give significantly lower scores for the factor "Learning materials and teacher" $(4.1 \pm 0.9$ students with grade point average $>4.5$ vs. $3.8 \pm 0.9$ students with grade point average $<3.5, \mathrm{~F}=5.103, \mathrm{p}=0.002$ ). Other factors do not illustrate significant differences between students according to the success in their studies.

\section{Factor Analysis: The Importance of the Existence of Certain E- Learning Elements in E-Courses}

Latent dimensions were determined by factor analysis $(\mathrm{KMO}=0,845$, and Bartlett's sphere test is statistically significant at the level of $p<0.001)$ under the component model using GK criterion for limiting factor extraction (higher than 1), basic solution was transformed into orthogonal varimax position. In the final factor model there were 10 variables, two factors were obtained which interpret $61.9 \%$ of the total variance, the first factor interprets $42.2 \%$ and the second one $19.8 \%$ of the total variance. Three statements $(4,5$ and 12 , see Table 2 .) were left out of the analysis, because they did not meet the requirements of the Thurston principle of the simple structure.

Similar to the instrument used for assessing the existence of certain elements, in this case as well a similar latent structure was obtained. However, the third factor was not obtained which can be interpreted as the absence of the mentioned elements, but can also be explained by the lesser importance that students attribute to certain elements.

The first factor involves six statements: 1, 2, 3, 10, 11 and 13 (Table 9.) and interprets $42.2 \%$ of the total variance. The statements refer to the perception of importance of the e-course elements such as organization, clarity, order and existence of the required materials, as well as other dimensions of the quality learning material. Furthermore, there are statements referring to the role of the teacher, and since regular editing of the materials and the feedback are also part of this factor, it is called "Learning materials and teacher".

The second factor consists of four statements: $6,7,8$ and 9 , and interprets $19.8 \%$ of the total variance. These statements refer to the importance students attribute to the e-course elements such 
as communication with other students and teacher/assistant, as well as communication via Forum, but also to the existence of the knowledge self-assessment tests. This factor is called "Online communication and activities".

Cronbach reliability coefficient is calculated for every set of variables in a certain factor. In the first factor, the Alpha coefficient was 0.842 (6 variables). In the second factor, the Alpha coefficient was 0.814 (4 variables).

When assessing importance, the factor "Learning materials and teacher" is rated significantly higher than the actual existence of corresponding elements ( $4.6 \pm 0.7$ vs. $4.0 \pm 0.9$, comparison with the data in Table 8.), while the factor "Online communication and activities" is assessed with the same score that is present for the existence of the corresponding elements $(3.7 \pm 1.2 \mathrm{vs} .3 .8 \pm$ 1.3, comparison with the data in Table 8.).

Table 9. The structure of latent dimensions: the importance of certain e-course elements.

\begin{tabular}{|c|c|c|c|c|c|c|c|c|}
\hline \multicolumn{2}{|c|}{ Factor title } & \multirow{2}{*}{$\begin{array}{l}\text { Statement } \\
\text { It is important to me that learning materials and ac- } \\
\text { tivities in the e-course are well organized. }\end{array}$} & \multicolumn{2}{|c|}{ Factor } & \multirow{2}{*}{$\begin{array}{r}\text { mean } \\
4.6\end{array}$} & \multirow{2}{*}{$\begin{array}{l}\text { SD } \\
0.7\end{array}$} & $\begin{array}{c}\text { Factor } \\
\text { mean }\end{array}$ & \multirow{2}{*}{$\begin{array}{l}\text { Fac- } \\
\text { tor } \\
\text { SD }\end{array}$} \\
\hline \multirow{6}{*}{ 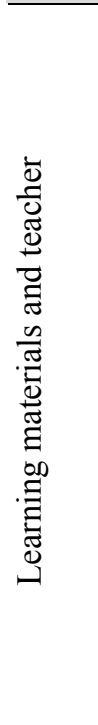 } & S3 & & $\begin{array}{c}1 \\
0.83\end{array}$ & 2 & & & \multirow{6}{*}{4.6} & \\
\hline & S11 & $\begin{array}{l}\text { It is important to me that e-course teacher edits con- } \\
\text { tent and manages e-course activities regularly. }\end{array}$ & 0.81 & & 4.7 & 0.6 & & \multirow{5}{*}{0.7} \\
\hline & S1 & $\begin{array}{l}\text { It is important to me that e-course provides all the } \\
\text { materials needed for achieving the expected learning } \\
\text { results. }\end{array}$ & 0.79 & & 4.6 & 0.7 & & \\
\hline & S2 & $\begin{array}{l}\text { It is important to me that learning materials in the e- } \\
\text { course are written in a clear and understanding man- } \\
\text { ner, that they are delicately colored, and have a sim- } \\
\text { ple standardized form. }\end{array}$ & 0.77 & & 4.5 & 0.7 & & \\
\hline & S13 & $\begin{array}{l}\text { It is important to me that I regularly receive feedback } \\
\text { about my work from e-course teacher. }\end{array}$ & 0.68 & & 4.6 & 0.7 & & \\
\hline & $\mathrm{S} 10$ & $\begin{array}{l}\text { It is important to me that e-course provides manda- } \\
\text { tory and optional study material in digital form. }\end{array}$ & 0.57 & 0.36 & 4.4 & 0.9 & & \\
\hline \multirow{4}{*}{ 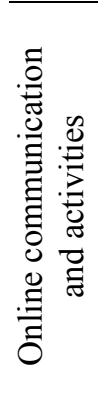 } & S7 & $\begin{array}{l}\text { It is important to me that through the e-course I com- } \\
\text { municate with other colleagues from the group. }\end{array}$ & & 0.90 & 3.4 & 1.3 & \multirow{4}{*}{3.7} & \multirow{4}{*}{1.2} \\
\hline & S8 & $\begin{array}{l}\text { It is important to me that e-course enables Forum dis- } \\
\text { cussions. }\end{array}$ & & 0.86 & 3.6 & 1.2 & & \\
\hline & S6 & $\begin{array}{l}\text { It is important to me that it is easy to communicate } \\
\text { with teacher/assistant through the e-course. }\end{array}$ & & 0.82 & 3.8 & 1.1 & & \\
\hline & S9 & $\begin{array}{l}\text { It is important to me that e-course provides ways to } \\
\text { test knowledge through self-assessment. }\end{array}$ & 0.35 & 0.52 & 3.9 & 1.1 & & \\
\hline
\end{tabular}

The scores for the factor of importance of certain e-learning elements were also analyzed according to the groups of students defined by independent variables. Regarding gender, there are significant differences in rating of the factor "Learning materials and teacher", where female respondents give significantly higher scores $(4.7 \pm 0.6$ vs. $4.5 \pm 0.7, \mathrm{t}=4.29, \mathrm{p}<0.001)$. According to field of study, there is a significant difference only in the first factor "Learning materials and teacher" where SSH students give it significantly higher importance than other groups of students $(4.7 \pm 0.6$ 
vs. 4.6 \pm 0.6 ICT students and 4.5 \pm 0.7 ENGMATSCI students, $\mathrm{F}=10.37, \mathrm{p}<0.001)$. Regarding study experience, the difference exists only in the factor "Online communication and activities", where least experienced students give significantly higher importance to these e-learning elements (score 3.9 \pm 1.1 with first year students, in contrast to $3.6 \pm 1.2$ with older students, $F=11.12$, $\mathrm{p}<0.001)$. According to experience with e-courses, there are differences in rating of both factors. The least experienced e-course users (up to one year) give significantly higher importance to the factor "Learning materials and teacher" ( $4.6 \pm 0.7$ vs. $4.4 \pm 0.6$ with experienced users, $t=2.01$, $\mathrm{p}=0.049)$, as well as to the factor "Online communication and activities" ( $3.8 \pm 1.1$ vs. $3.6 \pm 1.2$, $\mathrm{t}=3.31, \mathrm{p}<0.001)$. Regarding attitude towards courses, the respondents assess the importance of existence of certain e-learning elements differently; thus, the respondents who prefer traditional classroom courses give significantly lower importance to the factor "Learning materials and teacher" ( $4.4 \pm 0.8$ vs. $4.8 \pm 0.6$ online and $4.7 \pm 0.6$ blended courses, $F=17.23, \mathrm{p}<0.001)$, as well as to the factor "Online communication and activities" ( $3.1 \pm 1.1$ vs. $4.2 \pm 1.0$ online and $3.8 \pm 1.2$ blended courses, $\mathrm{F}=39.38, \mathrm{p}<0.001)$.

According to students' grade point average, there are differences in the factor "Learning materials and teacher", which better students value more than the less good students ( $4.6 \pm 0.6$ better students vs. $4.4 \pm 0.9$ students with grade point average $<2.5, \mathrm{~F}=4.18, \mathrm{p}=0.005)$.

\section{Factor Analysis: Attitudes towards E-Learning}

Latent dimensions were determined by factor analysis ( $\mathrm{KMO}=0,847$, Bartlett's sphere test is statistically significant at the level of $\mathrm{p}<0.001$ ) under the component model using GK criterion for limiting factor extraction (higher than 1), basic solution was transformed into orthogonal varimax position. All of the variables were included in the final factor model. Three factors were obtained which interpret $68 \%$ of the total variance, the first factor interprets $42.1 \%$, the second one 14.1 $\%$, and the third one $11.8 \%$ of the total variance.

The first factor consists of five statements: 14, 15, 16, 17 and 18 (Table 10.) and interprets $42.1 \%$ of the total variance. The statements refer to the specific features of blended courses, such as achieving better results in the courses which combine blended mode, better organization of learning and better suitability of the materials which are available at any time. Furthermore, students prefer e-courses because they become more active and complete their assignments more regularly than in the traditional classroom. This factor is called "Specific features of blended courses".

The second factor includes three statements: 19, 20 and 21, and interprets $14.1 \%$ of the total variance. The statements refer to the perception of better, easier and more effective communication, both with other students and the teacher/assistant. This factor is called "Online communication".

The third factor interprets $11.8 \%$ of the total variance and consists of only two statements (22 and 23). Internet is perceived as the source of distraction and loss of concentration due to the abundance of content that it offers. Furthermore, the statements refers to the importance of faceto-face contact to encourage learning process, therefore this factor is called "E-disruptors".

Cronbach reliability coefficient is calculated for every set of variables in a certain factor. In the first factor, the Alpha coefficient was 0.836 (5 variables). In the second factor, the Alpha coefficient was 0.854 ( 3 variables). In the third factor, the Alpha coefficient was 0.343 ( 2 variables), therefore, in future analysis additional variables should be added to this factor. 
Table10. Structure of latent dimensions: general attitudes towards e-learning.

\begin{tabular}{|c|c|c|c|c|c|c|c|c|c|}
\hline \multirow{2}{*}{\multicolumn{2}{|c|}{ Factor title }} & \multirow{3}{*}{$\begin{array}{l}\text { Statement } \\
\text { I achieve better results in the courses which } \\
\text { combine online and classroom mode of learn- } \\
\text { ing. }\end{array}$} & \multicolumn{3}{|c|}{ Factor } & \multirow{3}{*}{$\begin{array}{c}\text { mean } \\
3.5\end{array}$} & \multirow{3}{*}{$\begin{array}{r}\text { SD } \\
1.1\end{array}$} & \multirow{2}{*}{$\begin{array}{c}\text { Factor } \\
\text { mean }\end{array}$} & \multirow{2}{*}{$\begin{array}{l}\text { Factor } \\
\text { SD }\end{array}$} \\
\hline & & & 1 & 2 & 3 & & & & \\
\hline \multirow{5}{*}{ 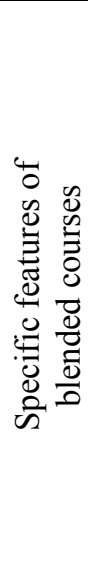 } & S15 & & 0.78 & 0.27 & & & & \multirow{5}{*}{3.7} & \multirow{5}{*}{1.2} \\
\hline & S14 & $\begin{array}{l}\text { E-course helps me to organize my learning } \\
\text { process better. }\end{array}$ & 0.77 & 0.25 & & 3.5 & 1.1 & & \\
\hline & S18 & $\begin{array}{l}\text { E-course learning materials are more suitable } \\
\text { for students' needs. }\end{array}$ & 0.73 & & & 3.7 & 1.0 & & \\
\hline & S17 & $\begin{array}{l}\text { It is important and useful to have unlimited ac- } \\
\text { cess to all the materials. }\end{array}$ & 0.70 & & & 4.5 & 0.9 & & \\
\hline & S16 & $\begin{array}{l}\text { In e-courses I participate more actively and } \\
\text { complete my assignments more regularly than } \\
\text { in exclusively classroom courses. }\end{array}$ & 0.69 & 0.40 & & 3.2 & 1.3 & & \\
\hline \multirow{3}{*}{ 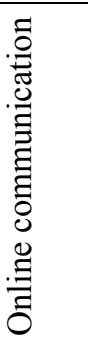 } & S20 & $\begin{array}{l}\text { Through e-course I communicate better with } \\
\text { other students about the learning topics, con- } \\
\text { tent and activities. }\end{array}$ & & 0.85 & & 2.6 & 1.2 & \multirow{3}{*}{2.7} & \multirow{3}{*}{1.3} \\
\hline & S21 & $\begin{array}{l}\text { E-courses provide easier communication with } \\
\text { teacher/assistant than it is in person. }\end{array}$ & & 0.83 & & 2.8 & 1.3 & & \\
\hline & S19 & $\begin{array}{l}\text { Discussions in e-course are more successful } \\
\text { than in the classroom. }\end{array}$ & 0.28 & 0.81 & & 2.8 & 1.3 & & \\
\hline \multirow{2}{*}{ 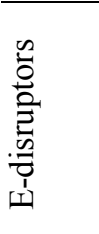 } & S23 & $\begin{array}{l}\text { It bothers me that in e-learning I am distracted } \\
\text { by other online activities (video games, social } \\
\text { networks, listening to music, etc.). }\end{array}$ & & & 0.84 & 3.1 & 1.4 & \multirow[t]{2}{*}{3.3} & \multirow[t]{2}{*}{1.3} \\
\hline & S22 & $\begin{array}{l}\text { Face-to-face contact with my teacher is fairly } \\
\text { important to encourage the learning process. }\end{array}$ & & -0.42 & 0.64 & 3.6 & 1.3 & & \\
\hline
\end{tabular}

Scores for certain factors in general attitudes towards e-learning were also analyzed according to the groups of students defined by independent variables. Regarding gender, there are no significant differences in attitudes in any of the factors. According to field of study, there is a significant difference only in the first factor, where the factor "Specific features of blended courses" receive significantly higher score from ICT students than from other respondents $(3.8 \pm 1.1 \mathrm{vs} .3 .6 \pm 1.2$ with all other students, $\mathrm{F}=3.39, \mathrm{p}=0.034)$. Regarding study experience, differences occur in the factor "Specific features of blended courses" and the factor "Online communication", where least experienced students give significantly higher score for these elements (score $3.8 \pm 1.1$ with first year students, in contrast to $3.6 \pm 1.2$ with older students, $\mathrm{F}=11.12, \mathrm{p}<0.001$ for the first factor and score $3.0 \pm 1.2$ with first year students, in contrast to $2.5 \pm 1.3$ with older students, $\mathrm{F}=14.21$, $\mathrm{p}<0.001$ for the second factor). According to e-learning experience, the differences in rating occur only in the factor "Online communication", where least experienced e-course users (up to one year) give significantly higher scores ( $2.8 \pm 1.3$ vs. $2.6 \pm 1.3$ with experienced users, $t=2.77$, $\mathrm{p}=0.006$ ). Regarding attitude towards the course, respondents express significantly different attitudes towards certain e-learning elements; thus, the students who prefer traditional classroom courses give lower scores for the factor "Specific features of blended courses" (3.0 $\pm 1.2 \mathrm{vs}$. $4.2 \pm 0.9$ online and $3.8 \pm 1.1$ blended courses, $\mathrm{F}=71.71, \mathrm{p}<0.001)$ and the factor "Online communi- 
cation" ( $2.1 \pm 1.1$ vs. $3.6 \pm 1.2$ online and $2.8 \pm 1.3$ blended courses, $F=40.26, p<0.001$ ), while the situation is completely opposite with the factor "E-disruptors" - the respondents who prefer traditional classroom courses give significantly higher scores than the others $(3.8 \pm 1.3$ vs. $2.6 \pm 1.3$ online and $3.3 \pm 1.3$ blended courses, $F=13.89, \mathrm{p}<0.001$ ). According to students' success in their studies (grade point average), there are no differences in the assessment of the attitudes towards e-learning.

\section{Conclusion}

As the e-learning support and platform is active in University of Rijeka only for two years, the primary objective of this study was to analyze the current state of student's perception and acceptance of e-learning as a new educational tool. Secondly, the aim of the study was to get the student's feedback on the value and importance of the specific elements of e-learning implemented in e-courses. Finally, the same study aimed at getting to know the student's general attitudes towards e-learning and detect their needs in blended courses.

The data collected through this research and obtained results were meant to serve as a feedback to all instances supporting e-learning implementation, to design guidelines for the teachers regarding student's needs and preferences in e-courses and to provide data on users' profiles.

The research was designed as a cross sectional study in which the data were collected through an online survey distributed to all students using e-learning platform at the time. The questionnaire was developed solely for the purpose of this study, but using the guidelines from similar researches on the acceptance of information technology and users' satisfaction (Bernard et al., 2004; Davis, 1989; DeLone \& McLean, 2003; Poelmans, 2009). Items were adapted to suit our research questions, namely to gather the data on the student's perception of quality of already delivered e-courses, to find out the level of importance for the specific elements of e-learning and to get to know student's general attitude toward e-learning as well as their needs with respect to quality of course materials, communication and support of the learning process,

The response rate was satisfactory and acquired sample representative of our students' population using e-learning tools with respect to socio-demographic characteristics and student's profiles.

Participants in the study asses the current state of e-learning elements implementation quite good; they agree the educational materials are in most cases complete, organized and well designed, and that teachers engage in online work well; they perceive the teachers manage the e-courses well, communicate regularly and timely provide the feedback. The lower level of agreement is obtained on the use of multimedia, offering of the self-assessment tests, accessibility of digital literature and collaborative activities. This suggests teachers should be encouraged (and trained) to put more effort in designing and offering suitable multimedia elements to enrich their materials, selfassessment test to make students feel more comfortable in terms of examination expectations, and to design online activities for the students to enhance collaborative aspects in teaching.

As the working with MudRi LMS is concerned, learners consider themselves sufficiently IT competent to successfully use e-courses and work with the system, and the majority agrees that MudRi is user friendly and has nice interface. Importantly, majority never have had problems with accessing nor with opening files on system. However, students are not well informed about the possibility to ask for technical assistance, suggesting that e-learning support service should work on informing users (particularly students) better.

The results from "general importance of specific e-learning elements" part of the survey indicate that students value the most the completeness, organization and design of educational materials, as well as teacher's online engagement, especially in good management of e-course, in regular communication and timely providing feedback. They do not perceive as much as important the 
online activities, communication to other students and discussions. When the comparison of "current state" and "general importance" for the specific e-learning elements is made, it seems that there is not much of discrepancy; the level of agreement with perceived state of implementation and wished state of implementation, is for all the elements just a small portion below (on average for 0,5 , on the scale of 1-5).

Assessing the general value of e-learning and its characteristic, students best agree with the notion that most important is to have the access to teaching materials $24 / 7$. Second best is that online materials are better suited to students' needs and that in general, having e-course as addition to classroom teaching is helping them organizing their learning better and overall achieving better results. They do not comply with statements of online discussions being more successful than classroom discussions and online communication to teachers and colleagues being better. Generally, the majority point out that $\mathrm{f} 2 \mathrm{f}$ communication to teachers is important in facilitating the learning process.

As the general attitude towards online learning is considered, it is interesting that preferences for exclusively online and/or blended learning are dominant in a group of students having better average studying grades (A or B), as well as in a group having shorter studying experience (1-2 ys of studying). The same groups find the new communication channels (online discussion forums, mailing with teachers, assistants and colleagues within the online learning environment) important and useful. Moreover, they think that online educational materials and activities are better suited to students' needs and that they help them achieve the learning outcomes better. This results is an important signal to all instances supporting e-learning implementation (from university management to supporting services), since it suggests that the "most wanted" users (students with better grades and fresh students) are those that willingly accept technology in learning.

However, irrespective of their learning preferences, the majority of student judge online discussions and online communication to teachers and colleagues to be not very valuable; this result points towards further investigation of quality of implementation of collaborative learning activities. Most probably this attitude arises from student's lack of good experience with online collaboration, suggesting the need to enhance teachers' competencies for online teaching, particularly in acquiring successful tutoring methods and learners' support methods (MacDonald, 2008; Wilson, 2004).

We think that continuous and careful monitoring of learner's satisfaction will ensure the success, feasibility and viability of online learning, as supporting educational tool in university study programs.

Blended learning systems change the way the learners learn (Graham, 2006), but also change the way the teachers teach. This process of transformation cannot happen overnight and is expected to last for some time, but we hope that it will bring alongside also some quality changes in organization, planning and management of higher education to our University, which can in turn bring about higher quality of education.

\section{References}

Bates, A. W. (1999). Managing technological change: Strategies for academic leaders. San Francisco: Jossey Bass.

Bernard, R. M., Brauer, A., Abrami, P. C., \& Surkes, M. (2004). The development of a questionnaire for predicting online learning achievement. Distance Education, 25(1), 31-47. Retrieved January 12, 2009, from the http://www.ebscohost.com/

Bonk, C. J. (2009). The world is open: How web technology is revolutionizing education. Jossey-Bass. 
Davis, F. D. (1989). Perceived usefullness, perceived ease of use, and user acceptance of information technology. MIS Quarterly, 13(3), 319-340.

DeLone, W., \& McLean, E. R. (2003). The DeLone and McLean model of information systems success: A ten-year update. Journal of Management Information Systems, 19(4), 9-30.

Duderstadt, J. J., Atkins, D. E., \& Van Houweling, D (2003). The development of institutional strategies. Educause Review, 38(3), 48-58.

Ehlers, U-D. (2004). Quality in e-learning from a learner's perspective. European Journal of Open, Distance and E-Learning. Retrieved September 12, 2010, from http://www.eurodl.org/index.php?article $=101$

Ellis, R. A., Jarkey, N., Mahony, M. J., Peat, M. \& Sheely, S. (2007). Managing quality improvement of eLearning in large, campus-based university. Quality in Higher Education, 15(1), 9-23.

Graham, C. R. (2006). Blended learning systems. In C. J. Bonk \& C. R. Graham, The handbook of blended learning: Global perspectives, local designs. Pfeiffer.

Hanna, E. D. (2003). Building a leadership vision - Eleven strategic challenges for higher education. Educause Review Magazine, 38(4), 25-34.

Keller, C., \& Cernerud, L. (2002). Students' perceptions of e-learning in university education. Journal of Educational Media, 27. Retrieved June 20, 2006 from http://www.tandf.co.uk/journals/titles/13581651.asp

MacDonald, J. (2008). Blended learning and online tutoring: Planning learner support and activity design. Gower Publishing Company.

McCradie, J. (2003). Does IT matter to higher education? Educause Review, 38(6), 15-22.

Poelmans, S., Wessa, P., Milis, K., Bloemen, E., \& Doom, C. (2009). Usability and acceptance of elearning in statistics education, based on the compendium platform. Retrieved May 12, 2010 from http://www.wessa.net/download/iceripaper1.pdf

Rončević, N., Ledić, J. \& Vrcelj, S. (2009). The predictive validity of the instrument and learning outcomes: A case study of hybrid teaching at the University of Rijeka. In Đ. Komlenović (Ed.), International Conference Quality and Efficiency of Teaching in Learning Society. Book of abstracts Beograd: Institut za pedagoška istraživanja, p. 251-251.

Wagner, G. D., \& Flannery, D. D. (2004). A quantitative study of factors affecting learner acceptance of a computer-based training support tool. Journal of European Industrial Training, 28(5), 383-399.

Wilson, G. (2004). Online interaction impacts on learning: Teaching the teachers to teach online. Australasian Journal of Educational Technology, 20(1), 33-48.

Žuvić-Butorac, M., \& Nebić, Z. (2009). Institutional support for e-learning implementation in higher education practice: A case report of University of Rijeka, Croatia. Proceedings of the International Conference on Information Technology Interfaces, ITI, art. no. 5196130, 479-484. 


\section{Biographies}

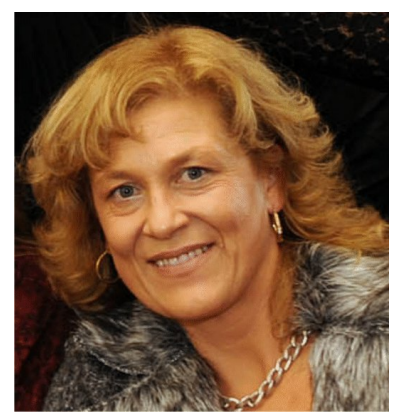

Marta Zuvic-Butoracreceived her PhD from the University of Zagreb, Croatia, in the field of biophysics. For 14 years she worked as a researcher and teacher at the School of Medicine, University of Rijeka, and after completing the education for an e-learning manager (joined studies UBC Canada and CARNet Croatia) she organized and is today heading the IT Academy and E-learning centre at the University of Rijeka.

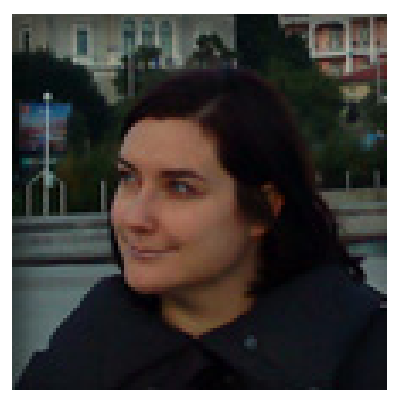

Nena Roncevic, MSc. is a teaching assistant and doctoral student at the University of Rijeka, Faculty of Humanities and Social Sciences in Rijeka, at Department of Education, Croatia. As junior researcher she currently works on two projects: Academic Profession and Societal Expectations: Challenges for University Civic Mission (http://euroac.ffri.hr/en/, part of a EUROCORES/ EUROHESC Programme of the European Science Foundation) and University and its Surroundings in the Context of European Integration Processes.

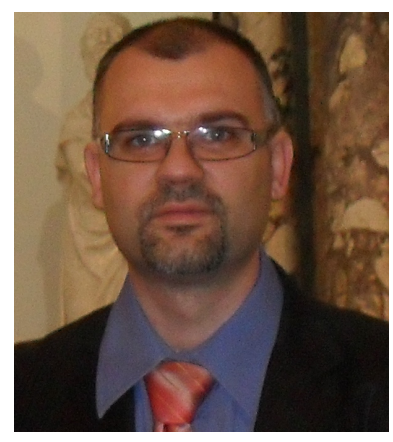

Damir Nemcanin received his MEd from the University of Rijeka, Croatia. He is currently a PhD student at the University of Zagreb. Initially he worked as software engineer and teacher of computer science at high school, currently he is working as teaching and research assistant and administrator of university e-learning system. His research interests include cloud computing, databases in cloud and implementation of e-learning in higher education.

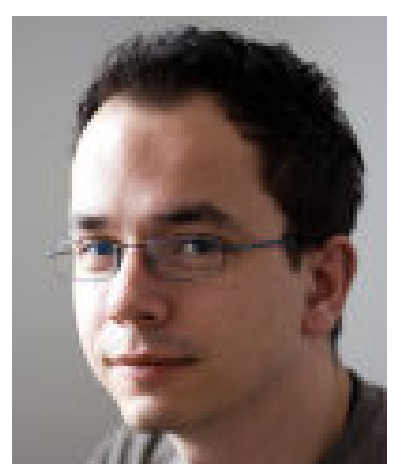

Zoran Nebic received his MEd from the University of Rijeka, Croatia. $\mathrm{He}$ is currently studying towards earning a $\mathrm{PhD}$ at the University of Ljubljana, Slovenia. After a period of working as a software engineer he gets employment with the University of Rijeka where he currently works in the area of life-long learning and professional education, and teaches a course in programming. His research interests include data mining and evolutionary computing. 